\title{
Black earths from Veneto and Piedmont (Northern Italy): origin, composition and potential use in different painting techniques
}

Giovanni Cavallo $0^{1,2^{*}}$ and Karin Gianoli Barioni ${ }^{3}$

\begin{abstract}
Terminology used to define black earths is general, vague and unclear with regard to the correspondence between the name of the pigment used in different epochs and its specific mineralogical and chemical composition. Furthermore, no distinction is reported in distinguishing organic and inorganic sources. Here, French, Spanish, German and Italian treatises and modern and contemporary literature have been consulted to understanding the use of this uncommon black pigment in different pictorial techniques. Polarizing Light Microscopy (PLM), X-Ray Diffraction (XRD) and X-Ray Fluorescence (XRF) analytical techniques are used to characterize both the raw materials collected in Veneto and Piedmont (Italy) and the black earths available on Italian and German markets. Results indicate that the studied materials are clay minerals rich compounds, in which the colouring fraction is due to the presence of carbonaceous matter and amorphous iron oxides. Depending on the microstructure, black shale and black chalk were identified. The properties of these materials when used in a fresco and a secco techniques are generally very good, as reported in the written sources, even if fading is observed when replicas were exposed in outdoor environment.
\end{abstract}

Keywords: Black earth, Black shale, Black chalk, Black ferruginous earths, Carbon-based pigments

\section{Introduction}

"Black earth" is a term that designates a large variety of black pigments including inorganic and organic compounds, such as mineral black (graphite), (black) iron oxides and carbon-based pigments [1,2]. This definition is vague, general and unclear; no specific indications are given about the origin of raw materials, their chemical and mineralogical composition or the use in decorative arts such as wall and mural paintings, the stability and permanence with organic and inorganic media. Chemical composition is reported for 'black earths' on 16th c. panels and canvas where sulphur-rich coal type black, Mn black, Sb black, Bi black and metallic powder such as tin-rich bronze and galena were identified [3]. An attempt to characterize black earth raw materials in Veneto (Italy), also including other Fe-based earths, was carried

\footnotetext{
* Correspondence: giovanni.cavallo@supsi.ch

${ }^{1}$ Dept. Earth and Environmental Sciences, University of Pavia, Via Ferrata 1 |-27010, Pavia, Italy

${ }^{2}$ Institute of Materials and Constructions, DACD SUPSI CH-6952, Canobbio, Switzerland

Full list of author information is available at the end of the article
}

out recently [4]; some analytical data are integrated and discussed here.

Other well-known earthy pigments where Fe is the characterizing and chromophore chemical element include "green earth" mainly constituted by celadonite $\mathrm{K}_{0.85}\left(\mathrm{Si}_{3.95}, \mathrm{Al}_{0.05}\right)\left(\mathrm{Fe}_{0.9}^{3+}, \mathrm{Fe}_{0.25}^{2+} \mathrm{Mg}_{0.6}, \mathrm{Al}_{0.25}\right) \mathrm{O}_{10}(\mathrm{OH})_{2}$ [5] and glauconite $\mathrm{K}_{(\mathrm{x}+\mathrm{y})}\left(\mathrm{Si}_{4-\mathrm{x}}, \mathrm{Al}_{\mathrm{x}}\right)_{\sim 4}\left(\mathrm{Fe}^{3+}, \mathrm{Al}, \mathrm{Mg}, \mathrm{Fe}^{2+}\right)_{\sim 2} \mathrm{O}_{10}(\mathrm{OH})_{2}$ where $0.2 \leq \mathrm{x} \leq 0.6$ and $0.4 \leq \mathrm{y} \leq 0.6[6]$; "yellow earth" is mainly goethite $\alpha-\mathrm{FeOOH}$ and lepidocrocite $\gamma-\mathrm{FeOOH}$; "red earth" is mainly hematite $\alpha-\mathrm{Fe}_{2} \mathrm{O}_{3}$; "Sienna earth" is richer in iron compared to yellow earth and contains $\mathrm{Mn}$ oxide; and "Umber earth" contains more iron and larger amounts of Mn-oxides than "Sienna earth" [7]. Depending on the environment of formation and related authigenic processes, clay minerals and other crystalline phases can also occur in these earth pigments [8].

Indications concerning the possible use of black painting raw materials occur in north-eastern Italy near Verona, where it is well known that earth pigments have been exploited since ancient times. According to Federici [9], "black earth" from San Giovanni Ilarione is a black coloured marl - due to the presence of carbonaceous 
matter - which is associated with basaltic rocks. During the 1940s three local mine owners exploited black earths and sold these as pigment to numerous local paint factories.

According to the available literature [10], black earths were also available in Piedmont.

Before starting analytical research on the raw materials and black earth pigments currently on the market, ancient written sources were considered in order to clarify the terminology referable to these materials; German, French, English, Italian and Spanish treatises have been consulted for this purpose, as described below.

Black earth pigments obtained from raw materials after mechanical and wet processing - and purchased from two paint factories were used to prepare a fresco and $a$ secco painting replicas. Pigments' properties such as hiding power, tinting strength, permanence to air and light, compatibility with the ground layer and with different media were assessed by visual examination; in addition, Munsell colours [11] were used to designate the pigments' changes of colour when mixed with inorganic and organic media and when exposed outdoors.

\section{Materials and methods}

\section{Consultation of written sources}

Written sources from Roman times to present were consulted; Table 1 lists the principal authors who described painting black materials having characteristics similar to those analysed in the present research. According to these historic written sources [12-22], black earths are materials containing iron-based and carbon-based compounds mixed with clay minerals.

Despite of the historical evidences attesting the use of black earths as painting materials in both $a$ fresco and $a$ secco techniques, there is very little analytical evidence of their use as painting material on architectural surfaces.

\section{Geological occurrences}

The location of the collected and analysed raw materials is reported in Figure 1. The black earth in Veneto (NE Italy) occurs near Bolca and is associated with the volcanic rocks (basaltic lava, basaltic tuffs and basaltic breccia) intruded into the Medium-Lower Eocene limestones (Nummulithic system) in the Rugolara Valley (San Giovanni Ilarione) and in the Alpone Valley [23]. In the same stratigraphic position, lignites and bituminous schists are also present. Bentonitic clays derived from the weathering of the volcanic materials occur in the upper part of the Medium-Eocene sequence. The mineralogical composition is represented mainly by montmorillonite, sometimes by kaolinite.

The black earths from Piedmont are related to deposits which occur in Boca and Vicoforte. The former occur within Pleistocene deltaic-lagoon and fluvial deposits; the black earth comes from clayey-rich lignite and turf horizons which are in the lower part of the sequence. The latter deposits occur in marsh and lacustrine environment which correspond to the subaerial weathering of the Triassic calcareous-dolomitic formation [10].

\section{Experimental}

Black earth samples (Table 2) were collected from outcrops around Verona, precisely about $1 \mathrm{Km}$ from the well-known fossiliferous area in Bolca. This material was processed using mechanical and wet treatments in order to separate the different grain size fractions, following methodologies adopted in the past centuries [10]. The

Table 1 Citations concerning 'black earth' in historic written sources

\begin{tabular}{|c|c|c|c|}
\hline Author & Period & Description & References \\
\hline Unknown author & $\begin{array}{l}\text { Roman } \\
\text { time }\end{array}$ & $\begin{array}{l}\text { Use of many organic and inorganic blackish compounds such as lignite, bitumen, bituminous } \\
\text { schists, graphite, pyrolusite and iron oxides. }\end{array}$ & [12] \\
\hline Pliny the Elder & $\begin{array}{l}\text { 2nd } c \text {. } \\
\text { A.D. }\end{array}$ & (...) "it is possible to obtain a black pigment from the earth". & {$[13]$} \\
\hline Cennino Cennini & $\begin{array}{l}15 \text { th } c . \\
\text { A.D. }\end{array}$ & $\begin{array}{l}\text { "Black is a black stone, soft and the color is fat; I found a stone coming from Piedmont good to } \\
\text { draw". }\end{array}$ & {$[14]$} \\
\hline Giorgio Vasari & $\begin{array}{l}\text { 16th } c \text {. } \\
\text { A.D. }\end{array}$ & A black earth called "terretta" (soft earth) which can be used a fresco painting is reported. & {$[15]$} \\
\hline Unknown French author & 1730 & "All earths and black stones can be used to paint a fresco and a secco". & {$[16]$} \\
\hline Unknown Spanish author & 1766 & "Black earth comes from Germany, is a natural earth and the color is black-bluish". & {$[17]$} \\
\hline Unknown German author & 1766 & $\begin{array}{l}\text { "A black material which is light, similar to clay, earth, is used to draw; it is very easy to obtain a } \\
\text { powder and, when washed, a black mud remains on the bottom". }\end{array}$ & {$[18]$} \\
\hline Wallerio J. Gotschalk & 1778 & "Ochra nigra argillacea" (black ochre containing clay minerals). & {$[19]$} \\
\hline Mouchon & 1779 & "Venice black is good for fresco painting and better than the Rome black earth". & {$[20]$} \\
\hline Don Antonio Palomino & 1795 & "Black earth, a mineral color, black, earthy, very important for fresco painting" & [21] \\
\hline Tilloch & 1803 & (...) "those earths called red, green, black or yellow are of an argillaceous-calcareous nature". & {$[22]$} \\
\hline
\end{tabular}




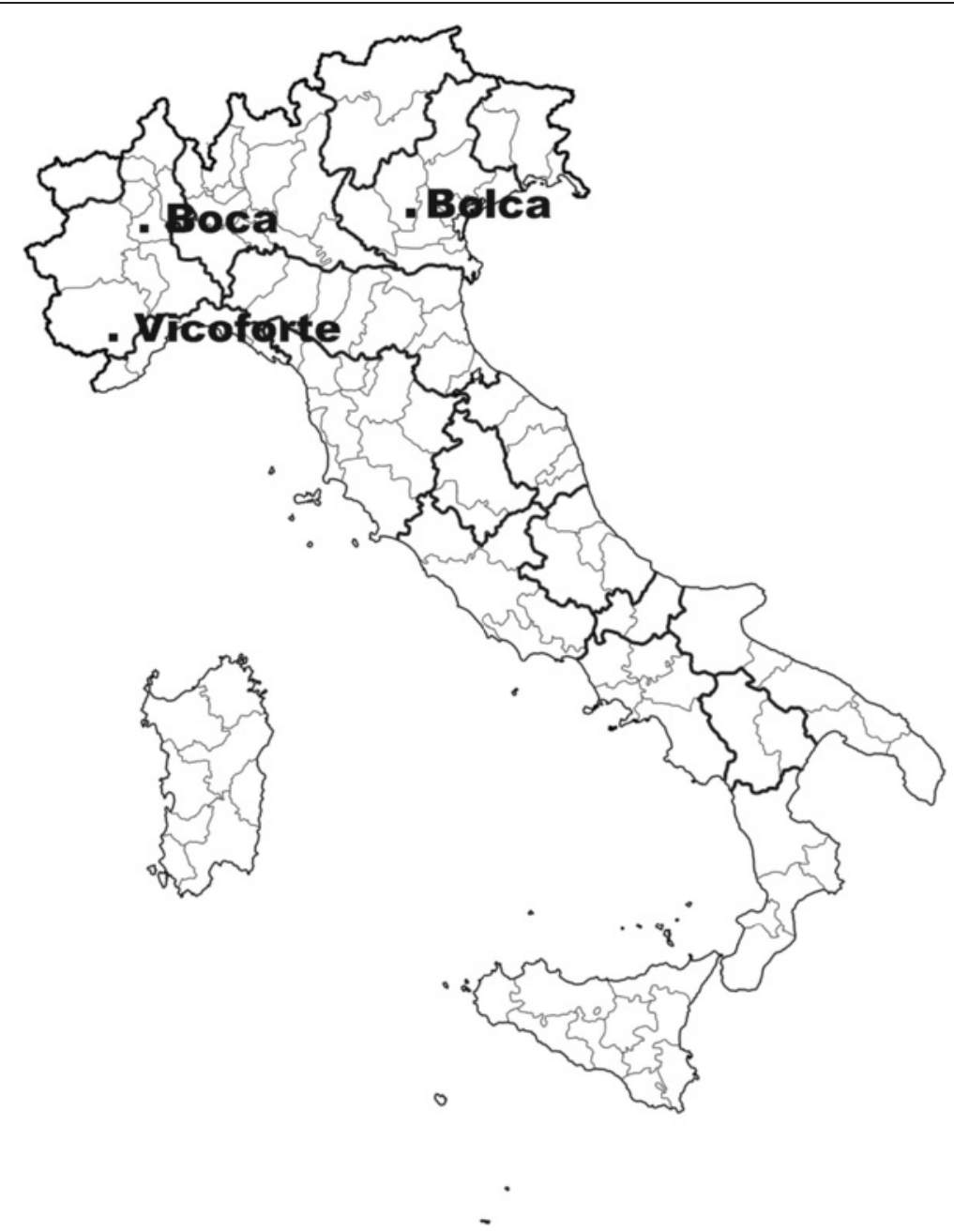

Figure 1 Schematic map of Italy with indication of the localities where black earths (raw materials) were sampled. Boca $\left(45^{\circ} 40^{\prime} 48^{\prime \prime} \mathrm{N} 8^{\circ}\right.$ $\left.24^{\prime} 35^{\prime \prime} \mathrm{E}\right)$ and Vicoforte $\left(44^{\circ} 21^{\prime} 53,64^{\prime \prime} \mathrm{N} 7^{\circ} 51^{\prime} 49,32^{\prime \prime} \mathrm{E}\right)$ in Piedmont; Bolca $\left(45^{\circ} 35^{\prime} 43^{\prime \prime} \mathrm{N} 11^{\circ} 12^{\prime} 36^{\prime \prime} \mathrm{E}\right)$ in Veneto.

Table 2 Description of the analysed samples

\begin{tabular}{|c|c|c|c|c|}
\hline ID & Description & Munsell Colour* & Source & Notes \\
\hline$\overline{B o l 1}$ & Massive black earth & $5 Y 3 / 2$ & Bolca, Veneto, Italy & Raw material \\
\hline Bol1a & Same that Bol1, after crushing and sieving & & & $\varnothing>250 \mu \mathrm{m}$ \\
\hline Bol1b & Same that Bol1, after crushing and sieving & & & $250 \mu \mathrm{m} \leq \varnothing \leq 125 \mu \mathrm{m}$ \\
\hline Bol1c & Same that Bol1, after crushing and sieving & & & $\varnothing<125 \mu \mathrm{m}$ \\
\hline Bol1d & Same that Bol1, after 10 washing cycles & N1 & & Suspended material \\
\hline Bol1e & Same that Bol1, after 10 washing cycles & $5 Y R 4 / 4$ & & Precipitated material \\
\hline Boc2 & Massive black earth & N1 & Boca, Piedmont, Italy & Raw material \\
\hline TN01 & Massive black earth & $5 Y 3 / 2$ & Paint factory collection, Veneto, Italy & Raw material \\
\hline TN01A & Powder black earth & $5 Y 3 / 2$ & Paint factory, Veneto, Italy & Material sold as black earth \\
\hline TN-K & Massive black earth & $5 Y R 2 / 2$ & Paint factory, Germany & Material sold as black earth \\
\hline TN-VF & Massive black earth & $5 Y R 3 / 4$ & Vicoforte, Piedmont & Raw material \\
\hline TO-K & Umber earth, powder & $5 Y 3 / 2$ & Paint factory, Germany & Material sold as Umber earth \\
\hline TR-D & Rome earth, powder & $5 Y R 2 / 1$ & Paint factory, Veneto, Italy & Material sold as Rome earth \\
\hline
\end{tabular}

* Munsell colour notations refer to the powder for all of the listed samples. 
mechanical separation was done by gently crushing the material in an agate mortar with a pestle and sieving three grain sizes: coarse $(\varnothing>250 \mu \mathrm{m})$, medium $(250 \mu \mathrm{m} \leq \varnothing \leq 125 \mu \mathrm{m})$ and fine $(\varnothing<125 \mu \mathrm{m})$. The wet system is based on several washing treatments that separates the material in suspension from that deposited on the bottom of a plastic box. The colour of the material precipitated on the bottom is surprisingly black, as described by Lewis [18] in 1766. This processing treatment was applied only for samples coming from Bolca (Bol in Table 2); it was not possible to directly collect the materials from outcrops in Piedmont because the mines are still operating and permission to obtain samples was denied. Instead, material (samples Boc2 and TN-VF) was kindly provided by the Polytechnic of Turin (Italy).

To have reference comparisons, black earths available on the market (samples TN-01, TN-01a, TN-K, TO-K, TR-D) were analysed as well.

The microstructure of the massive raw materials was analysed with Polarizing Light Microscopy (PLM) both in transmitted and reflected light using a Zeiss Axioskop 40 polarizing microscope. Powder X-ray Diffraction (XRD) identified the relative abundance of mineralogical phases. Analysis was carried out on bulk samples and randomly oriented powder specimens were prepared, using a Philips X' Pert Pro type PW 3040/60 diffractometer and X-ray tube with $\mathrm{Cu}$ anti-cathode $(40 \mathrm{kV}$, $20 \mathrm{~mA})$, working conditions: speed $1^{\circ}(2 \theta / \mathrm{min})$ and measurement range $2^{\circ}-65^{\circ} 2 \theta$.

Minerals are indicated, where necessary, using standard mineral names abbreviations [24].

$\mathrm{X}$-Ray Fluorescence (XRF) determined the quantitative chemical composition of the major elements. Chemical composition is a complementary tool for XRD allowing the correlation between major elements and crystals, poorly crystalline and amorphous compounds such as oxides and hydroxides and was very useful in this study case. XRF analyses were performed on tablets of pressed powder using a solution of elvacite $15 \%$ in acetone as binder, and a Philips PW 1480 automatic spectrometer equipped with a X-ray tube with $\mathrm{Cr}$ anode $(70 \mathrm{kV}$, $30 \mathrm{~mA}$ ). LOI (Loss on Ignition) values were calculated as loss in weight after heating at $1000^{\circ} \mathrm{C}$ and the elimination of hydration water at $110^{\circ} \mathrm{C}$.

\section{Results}

\section{Polarizing Light Microscopy (PLM)}

PLM was carried out on the weakly cemented raw materials collected from the outcrops in Veneto (samples labelled Bol and TN01) and in Piedmont (samples labelled Boc and TN-VF). Samples coming from Bolca exhibit a parallel laminated microstructure and a dark colour in transmitted light (Figures 2, 3); mineral phases are not recognized (grain size below the resolution of the microscope) except for pyrite for its characteristic habit and optical properties under reflected light [4]. Carbonaceous material is also present as reported in Figure 4. Samples coming from Boca (Figures 5, 6) exhibit massive texture, a clayey matrix with relic quartz, carbonaceous material and traces of reddish Fe-oxides. Sample from Vicoforte (TN-VF) displays a massive texture, a clayey-rich matrix with detrital quartz, traces of muscovite, carbonaceous material (Figures 7, 8). Pyrite was clearly detected (Figure 9); in addition Fe-oxides deriving from pyrite alteration were detected.

\section{X-Ray Diffraction (XRD)}

Samples coming from Bolca (labelled Bol) and the paint factory in Veneto (labelled TNs) display the presence of calcite $\left(\mathrm{CaCO}_{3}\right)$ and clay minerals of the smectite group, most probably poorly crystallized montmorillonite (Figure 10). Pyrite $\left(\mathrm{FeS}_{2}\right)$ is an accessory constituent [4].

The samples after mechanical grinding and sieving (Bol1a, 1b, 1c) display calcite/montmorillonite (Cal/ Mon) intensity ratios that are quite different compared to the intensity ratio before the grain size separation (Bol1); Cal/Mon increases with sieving. The same result is observed after washing; the material that remains in suspension, which is brownish in colour, has a Cal/Mon ratio that is higher than the black material collected from the bottom deposit. Ten washing cycles were necessary for an accurate separation of the various fractions.

Sample coming from Boca in Piedmont (Boc2) is composed by clay minerals such as montmorillonite and kaolinite $\left[\mathrm{Al}_{2} \mathrm{Si}_{2} \mathrm{O}_{5}(\mathrm{OH})_{4}\right]$; quartz is an accessory mineral. Black earth coming from another area (Vicoforte, TN-VF) is composed mainly by quartz and illite-muscovite

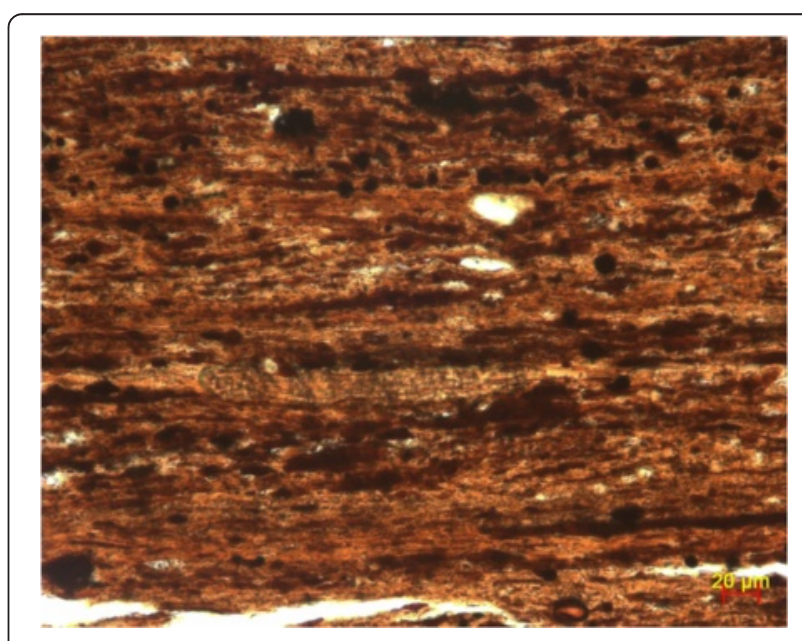

Figure 2 Black earth (colour notation: $5 Y$ 3/2) from Bolca (Bol1): micrograph (PPL) shows a parallel laminated microstructure. 


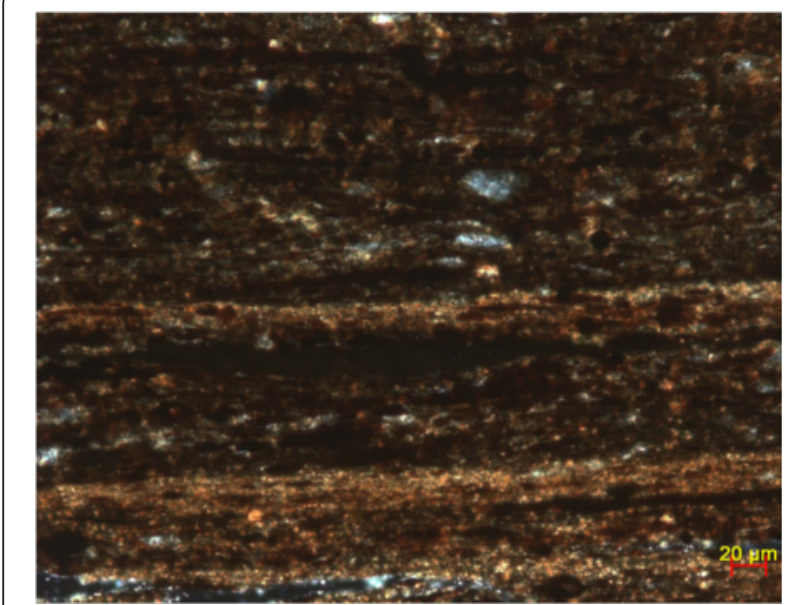

Figure 3 Micrograph description as in Figure 1 (XPOL).

$\left(\mathrm{KAl}_{2}\left[\mathrm{AlSi}_{3} \mathrm{O}_{10}(\mathrm{~F}, \mathrm{OH})_{2}\right]\right)$; pyrite is an accessory mineral phase, confirming observations under optical microscope.

The mineralogical composition of the material sold by a historic paint factory in Veneto as black earth (sample TN01A) is the same as the raw materials collected in the sampling area around Bolca (samples Bol and TN01) except for the presence of gypsum $\left(\mathrm{CaSO}_{4} \cdot 2 \mathrm{H}_{2} \mathrm{O}\right)$. The mineralogical composition of sample TR-D (sold as Terra Roma - Rome earth) is almost the same as that of the samples from Bolca.

The mineralogical composition of sample TN-K (sold as black earth by another paint factory in Germany) is quartz, illite (similar to muscovite but with higher content in $\mathrm{SiO}_{2}$ and $\mathrm{H}_{2} \mathrm{O}$ and less in $\mathrm{K}_{2} \mathrm{O}$ ) and jarosite, a $\mathrm{K}$, Fe-sulphate with formula $\mathrm{KFe}_{3}\left(\mathrm{SO}_{4}\right)_{2}(\mathrm{OH})_{6}$.

Finally, the sample TN-O ("Umber Earth") contains montmorillonite, gypsum and quartz.

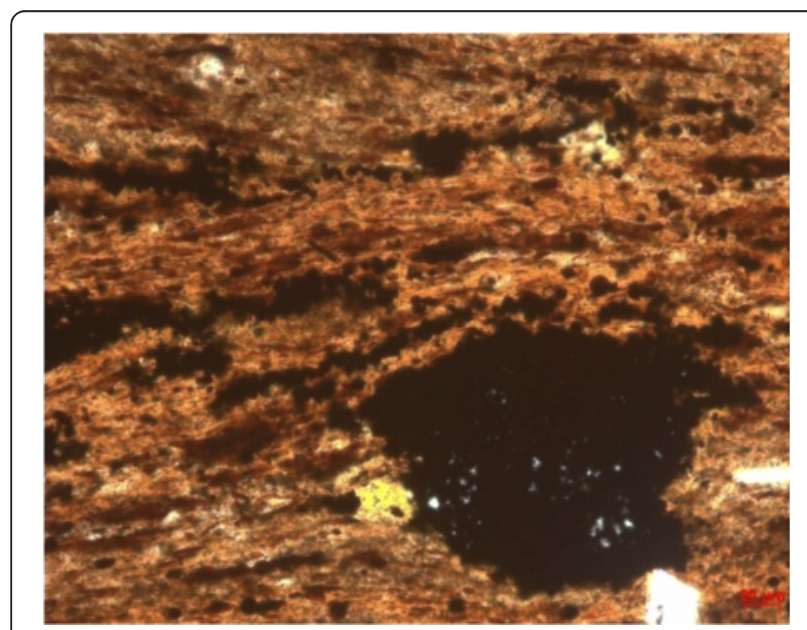

Figure 4 Sample from Bolca (Bol1): micrograph (PPL) exhibits a relic of C-based material in a clayey matrix.

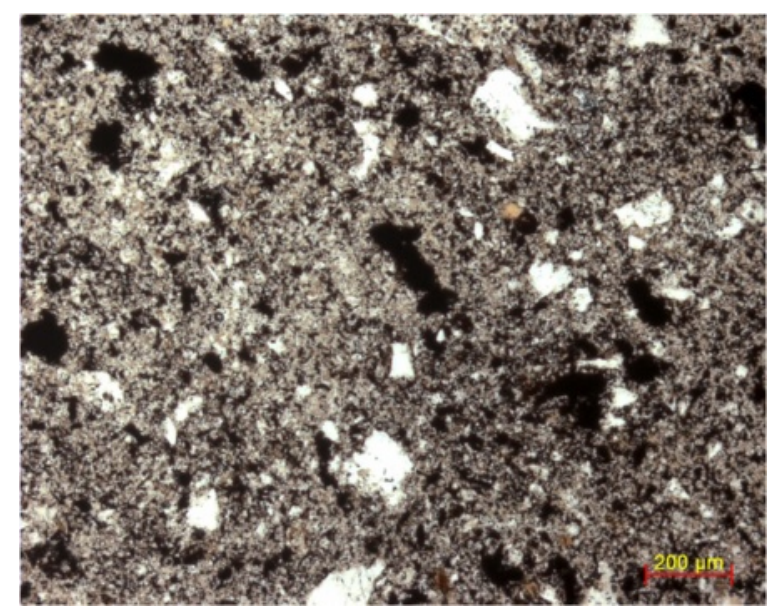

Figure 5 Black earth (colour notation: N1) from Boca (Boc2): micrograph (PPL) shows a clay-rich ground mass; black material irregular in shape and size is due to C-based matter. Detrital quartz is present as well.

\section{X-Ray Fluorescence (XRF)}

The results of the chemical analysis of the major elements are listed in Table 3; the values already presented in [4] are reported in italic.

Major elements are strictly related to the mineralogical compositions of the analysed samples. $\mathrm{Fe}_{2} \mathrm{O}_{3}$ values are high except for the samples Boc2 (0.55\%) and TN-K (3.65\%). The high iron content is most likely related to the presence of amorphous or very poorly crystalline Feoxides and/or Fe-hydroxides not detected with XRD. The high $\mathrm{CaO}$ content of samples Bol, TN01, TN01a, TR-D is due to the presence of calcite. LOI is correlated with calcite $\left(\mathrm{CO}_{2}\right)$ and clay minerals $(\mathrm{OH}) . \mathrm{SiO}_{2}, \mathrm{Al}_{2} \mathrm{O}_{3}$ and $\mathrm{MgO}$ contents correlate well with smectite (samples Bol, TN01, TN01a, TO-K, TR-D); $\mathrm{SiO}_{2}, \mathrm{Al}_{2} \mathrm{O}_{3}$ and $\mathrm{K}_{2} \mathrm{O}$

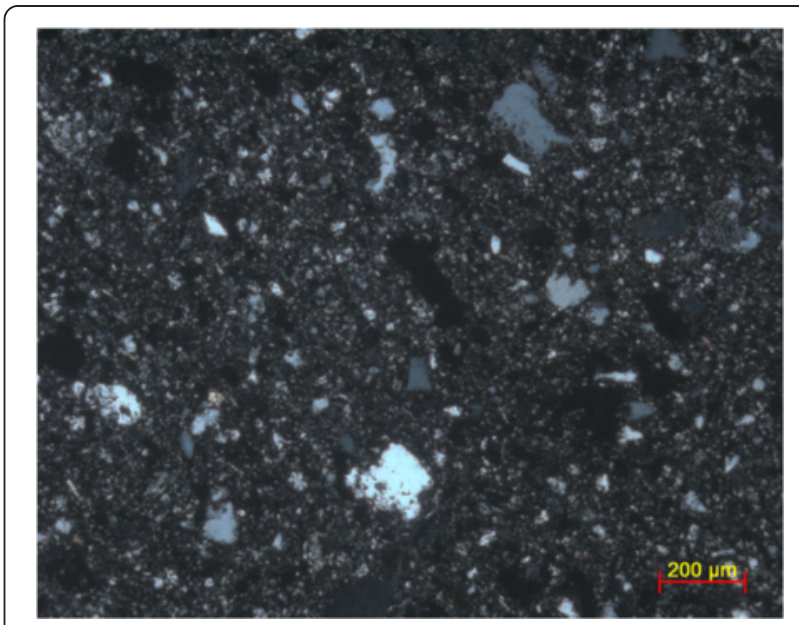

Figure 6 Micrograph description as in Figure 3 (XPOL). 


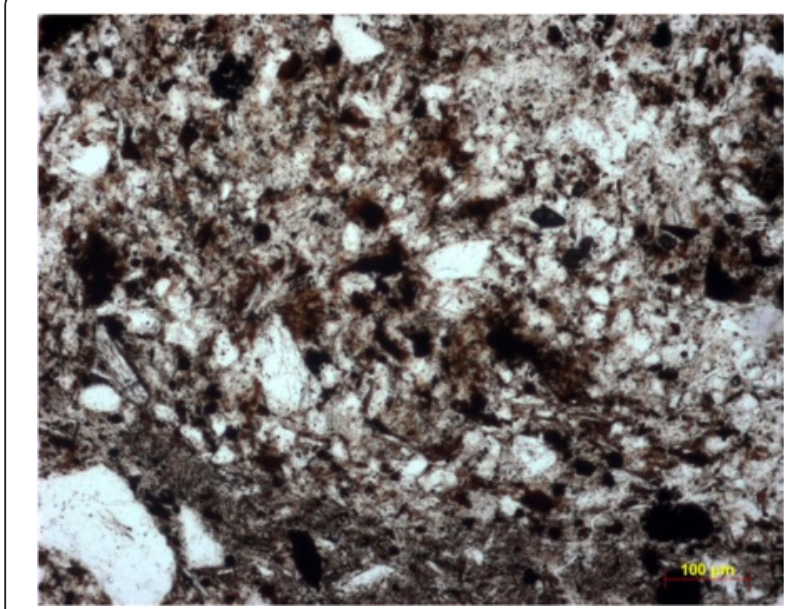

Figure 7 Black earth (colour notation: 5YR 3/4) from Vicoforte (TN-VF): micrograph (PPL) shows a clayey-rich ground mass, opaque minerals, C-based matter and detrital quartz. Reddish iron-oxides are spread within the matrix.

with illite and muscovite (samples TN-K and TN-VF); $\mathrm{SiO}_{2}, \mathrm{Al}_{2} \mathrm{O}_{3}$ with kaolinite (sample Boc2) and $\mathrm{SiO}_{2}$ with quartz (samples Boc2, TN-K, TN-VF, TO-K).

The low content of alkalis $\left(\mathrm{Na}_{2} \mathrm{O}\right.$ and $\left.\mathrm{K}_{2} \mathrm{O}\right)$ which are highly mobile elements in most crustal processes and the inverse correlation between $\mathrm{SiO}_{2}$ and $\mathrm{TiO}_{2}$ (Figure 11) suggest that the mineral phases come from authigenic hydration and alteration processes. Two samples (TO-K and TR-D) have a measurable amount of $\mathrm{MnO}$ indicating they are Umber earths.

\section{Replica preparation}

The collected raw materials and those purchased on the market were used to test different manual properties of the black pigments, such as compatibility with inorganic

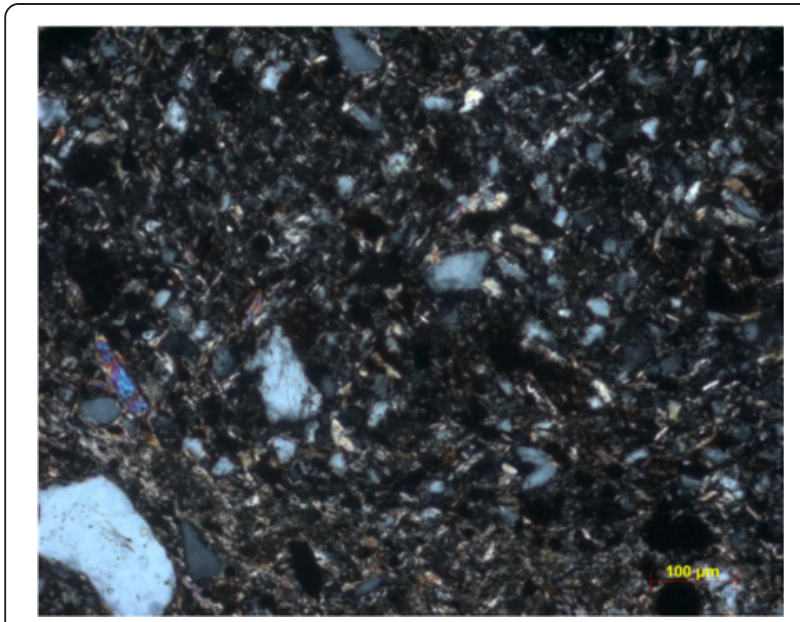

Figure 8 Micrograph description as in Figure 8 (XPOL).

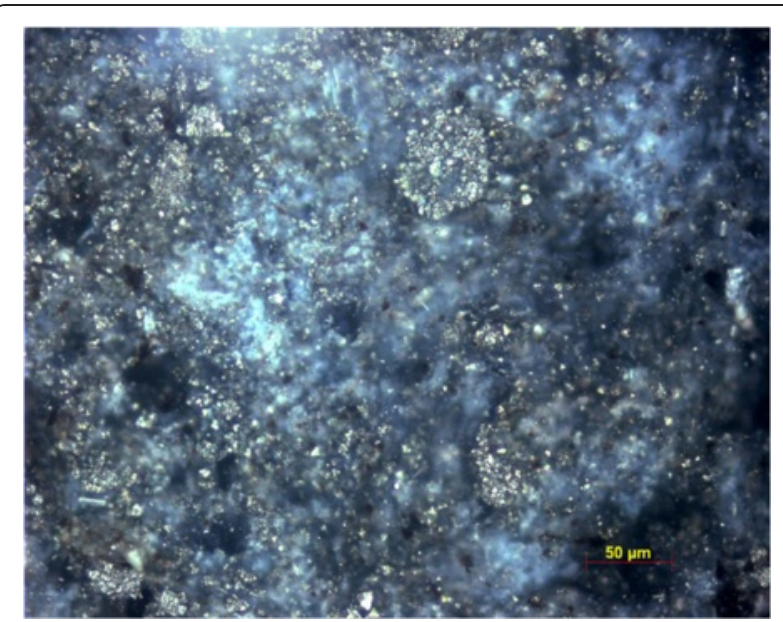

Figure 9 Black earth from Vicoforte (TN-VF): cluster of pyrite under reflected light detected thanks to the characteristic metallic brightness and habit.

and organic media, compatibility with the support, hiding power, tinting strength, workability with a brush and permanence in air and sunlight within a semi-confined environment, protected from the action of rainfall. The visual observations were done after 3-months of natural aging and compared with a non-aged replica by photographic documentation. Colour notations were documented according to Munsell colours [11] in order to evidence their changes when mixed with different organic and inorganic media and when exposed to air. These variations were reported on Table 4. The following painting techniques were replicated: a fresco, with lime (Figure 12), caseinates (Ca-caseinate 3\%, 5\% and ammonium caseinate), linseed and nut oil, animal glue and eggs.

Among the different fractions extracted from the raw materials collected at Bolca (Veneto), the best performance was obtained using the suspended material collected after the evaporation of water (Bol1d), particularly in the a fresco, egg and oil temperas. The colour fades, however, when the pigment is mixed with lime. The stability in air and light is not particularly good for all the tested techniques. The same results occur in the pigments labelled TN (raw and processed) coming from the same district (Table 4).

Black earths from Boca (Piedmont) exhibit good properties; the best tinting strength was observed a fresco, with oil, egg and glue. When mixed with lime, however, the final shade becomes greyish. The hiding power is very good in all the pictorial techniques except with animal glue and caseinates; in these cases, the pigment fades when exposed outdoors (Table 4). Black earth from Vicoforte (Piedmont) exhibits good properties which are improved particularly when mixed with oil and egg. The lime technique improves the hiding power, even if the 


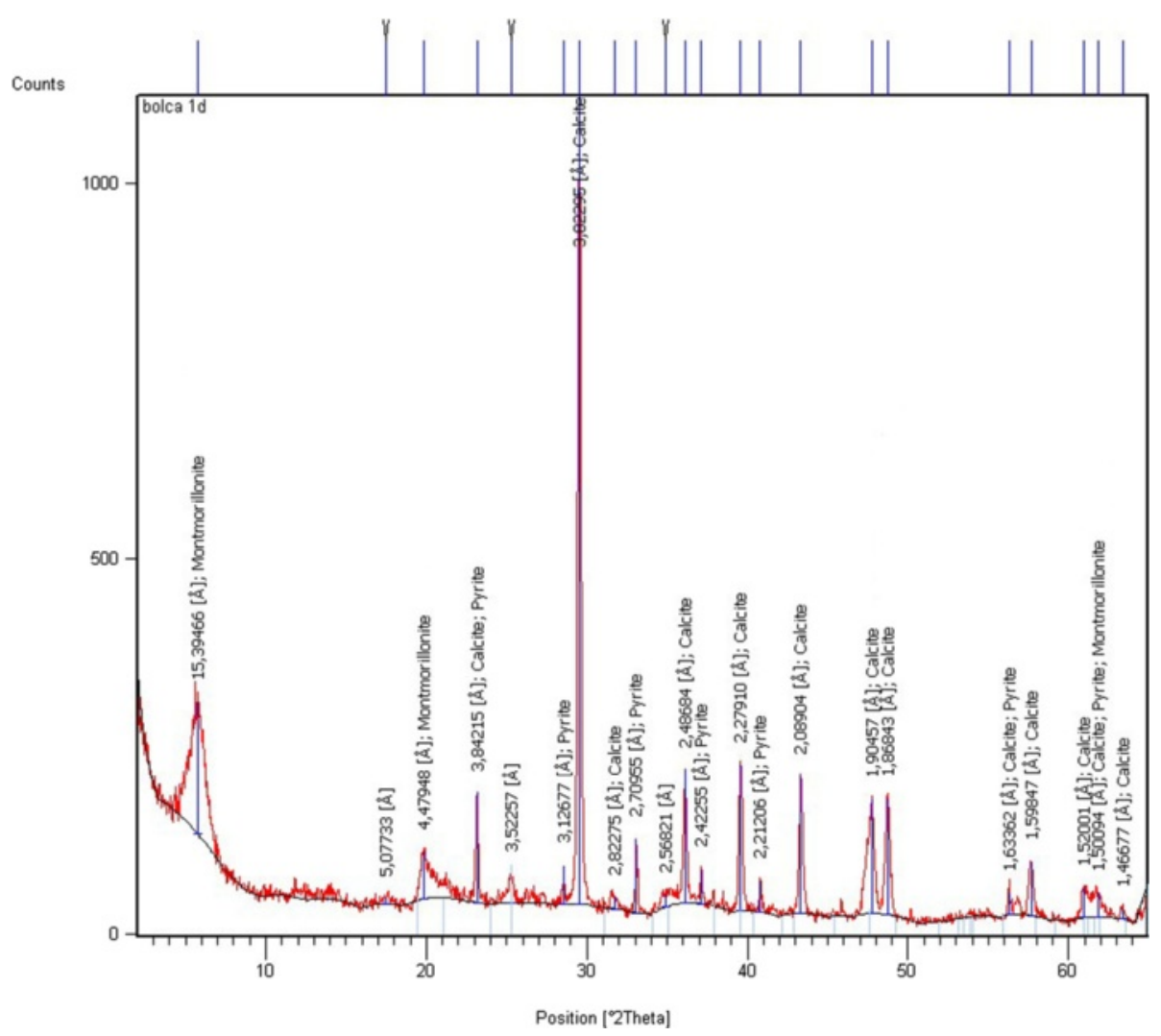

Figure 10 XRD of the black earth from Bolca: the graph shows the low crystallinity of the raw materials particularly marked by the broad reflections of montmorillonite.

final colour becomes greyish, as well as when the pigment is mixed with animal glue. The hiding power when used a fresco decreases compared with the caseinate techniques; the caseinate does, however, exhibit a greyish coloration. The stability when the replicas are exposed outdoors is good when mixed with egg, oil and a fresco (Table 4).

The remaining pigments sold as Rome earth (TR-D), black earth (TN-K) and Umber earth (TO-K) exhibit good properties and good stability and permanence when exposed outdoors.

Table 3 Chemical analysis of the major elements (values in wt\%)

\begin{tabular}{|c|c|c|c|c|c|c|c|c|c|c|c|}
\hline ID & $\mathrm{SiO}_{2}$ & $\mathrm{TiO}_{2}$ & $\mathrm{Al}_{2} \mathrm{O}_{3}$ & $\mathrm{Fe}_{2} \mathrm{O}_{3}$ & $\mathrm{MnO}$ & $\mathrm{MgO}$ & $\mathrm{CaO}$ & $\mathrm{K}_{2} \mathrm{O}$ & $\mathrm{Na}_{2} \mathrm{O}$ & $\mathrm{P}_{2} \mathrm{O}_{5}$ & LOI \\
\hline Bol1* & 25.07 & 1.55 & 7.84 & 5.16 & 0.05 & 1.81 & 13.20 & 0.28 & 0.05 & 0.37 & 44.63 \\
\hline Bol1b & 20.72 & 1.67 & 7.60 & 7.90 & 0.09 & 1.72 & 20.71 & 0.18 & 0.05 & 0.38 & 38.97 \\
\hline Bol1a & 20.33 & 1.62 & 7.44 & 7.64 & 0.10 & 1.71 & 20.56 & 0.17 & 0.06 & 0.38 & 39.98 \\
\hline Bol1c & 19.35 & 1.58 & 7.13 & 7.94 & 0.17 & 1.74 & 24.07 & 0.17 & 0.06 & 0.38 & 37.40 \\
\hline Bol1d & 18.56 & 1.47 & 6.79 & 7.72 & 0.19 & 1.75 & 25.18 & 0.15 & 0.06 & 0.36 & 37.76 \\
\hline Bol1e & 20.63 & 1.62 & 7.54 & 7.45 & 0.09 & 1.69 & 19.19 & 0.16 & 0.05 & 0.38 & 41.19 \\
\hline TNOI $^{*}$ & 26.61 & 2.13 & 8.83 & 8.07 & 0.10 & 2.00 & 18.34 & 0.13 & 0.05 & 0.37 & 33.36 \\
\hline TN-VF & 57.90 & 0.58 & 15.14 & 7.40 & 0.07 & 2.23 & 0.43 & 3.32 & 0.25 & 0.03 & 12.65 \\
\hline Boc2 & 79.83 & 0.64 & 8.82 & 0.55 & 0.03 & 0.13 & 0.51 & 0.27 & 0.05 & 0.00 & 9.18 \\
\hline TNO1A* & 26.01 & 2.05 & 8.95 & 9.19 & 0.15 & 2.13 & 18.48 & 0.20 & 0.06 & 0.40 & 32.38 \\
\hline TN-K & 58.58 & 0.76 & 5,43 & 3.65 & 0.02 & 0.45 & 0.19 & 1.42 & 0.13 & 0.16 & 29.21 \\
\hline TO-K & 40.42 & 1.08 & 12.44 & 16.80 & 4.69 & 2.86 & 7.79 & 0.63 & 0.33 & 0.30 & 12.66 \\
\hline TR-D & 25.50 & 0.65 & 7.88 & 13.55 & 2.13 & 2.02 & 23.95 & 0.46 & 0.47 & 0.27 & 23.12 \\
\hline
\end{tabular}

* Data from [4]. 


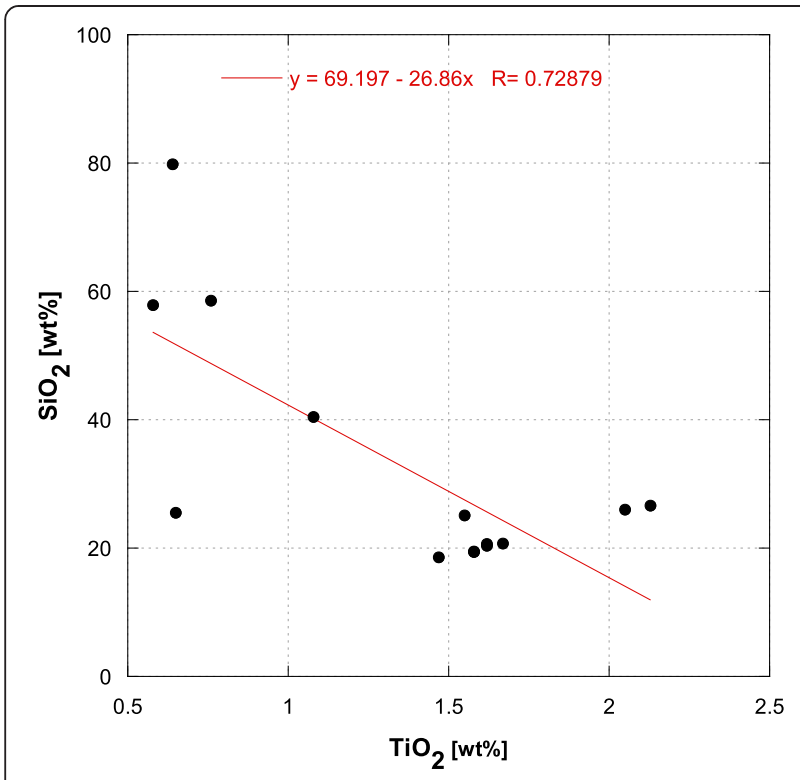

Figure 11 Binary diagram $\mathrm{SiO}_{2}$ vs $\mathrm{TiO}_{2}$ showing an inverse correlation.

Finally, charcoal black was tested. All properties are good even if the stability in the external environment is not particularly good as the pigment fades (Table 4).

\section{Discussion}

Petrographic, mineralogical and chemical analysis of natural black earths define the nature of black earth materials, even though some uncertainties remain as concerns the nature of Fe-oxides - especially since all the samples show amorphous phases.

Analyses on samples coming from outcrops in Veneto (samples Bols and TNs) indicate they are black shale, with clay minerals represented by poorly crystalline montmorillonite. The black colour is due to the presence of carbonaceous matter and most probably to Fe-oxides such as magnetite and/or oxide-hydroxides undetected under XRD because they could be amorphous phases and occur in low concentrations $(<\mathrm{LOD})$. The presence of pyrite in association with organic matter is characteristic of anoxic environments [25]. In addition, sample TN01 (a commercially available black earth) exhibits the same composition of the raw materials (samples $\mathrm{TN}$ and $\mathrm{Bol}$ ) but with discrete quantity of gypsum. This could be due to an intentional addition as extender. Gypsum was also found in the sample Umber earth (TO-K) even if the mineralogical paragenesis indicates a different origin than TN01. The sample sold as Rome earth (sample TR-D) has the same mineralogical composition as the $\mathrm{TN}$ and $\mathrm{Bol}$ samples, although the amounts of $\mathrm{Fe}$ and $\mathrm{Mn}$ are higher (13.55\% and $2.13 \%)$. The presence of calcite in all the samples coming from Veneto is related with the parent rocks which are Medium-Lower Eocene limestones.

The sample collected from Vicoforte (Piedmont) is similar to the sample sold as black earth by another paint factory (sample $\mathrm{TN}-\mathrm{K}$ ) in terms of mineralogical composition.

The black earth coming from the outcrop in Boca (Piedmont) is different in terms of microstructure and chemical composition. Observations under optical microscope show that clay minerals are not oriented along preferential planes and the Fe content detected by $\mathrm{XRF}$ is quite low, when compared with the remaining samples $\left(\mathrm{Fe}_{\mathrm{wt} \%}=0.55\right)$. Detrital quartz was also detected. The colour is apparently due to the presence of carbonaceous matter randomly distributed through the clay matrix. No gypsum was identified. This sample can be classified as black chalk.

Overall, these materials correlate well with the descriptions in treatises having clay minerals as basic constituents. Concerning the procedures to separate the different fractions, the Bols samples, for example, some considerations arise. Assuming that $\mathrm{SiO}_{2}, \mathrm{Al}_{2} \mathrm{O}_{3}$ and $\mathrm{MgO}$ concentrations are all associated with montmorillonite and $\mathrm{CaO}$ to calcite, the mechanical grinding and the dry sieving determine a relative enrichment in calcite respect to montmorillonite (see geochemical data in Table 3) as also observed

Table 4 Munsell colour notations for the black earths used in different painting techniques.

\begin{tabular}{|c|c|c|c|c|c|c|c|c|c|c|c|c|}
\hline \multirow{3}{*}{$\begin{array}{l}\text { Pigment } \\
\text { Bol1d }\end{array}$} & \multicolumn{12}{|c|}{ Painting techniques } \\
\hline & \multicolumn{2}{|l|}{ A fresco } & \multicolumn{2}{|l|}{ Lime } & \multicolumn{2}{|c|}{ Egg tempera } & \multicolumn{2}{|c|}{ Oil tempera } & \multicolumn{2}{|c|}{ Glue tempera } & \multicolumn{2}{|c|}{ Caseinate } \\
\hline & 5YR 4/4 & $10 R 5 / 4$ & 5YR 5/6 & $5 Y R 6 / 4$ & $10 \mathrm{R} 8 / 2$ & $10 R 3 / 4$ & $5 R 2 / 6$ & $10 R 5 / 4$ & 5YR 4/4 & IOYR 5/4 & 5YR 5/6 & $5 Y R 6 / 4$ \\
\hline TR-D & $5 Y R 2 / 1$ & $5 Y R 2 / 1$ & $5 Y R 2 / 1$ & $5 Y R 2 / 1$ & $\mathrm{~N} 2$ & N3 & N2 & N3 & N4 & N4 & YR 2/2 & $5 Y 3 / 2$ \\
\hline TN-K & $5 Y R 2 / 1$ & $5 Y R 2 / 1$ & $5 Y R 2 / 1$ & $5 Y R 2 / 1$ & $\mathrm{~N} 2$ & N3 & $\mathrm{N} 2$ & N3 & N2 & N3 & $5 Y 3 / 2$ & $5 Y 3 / 2$ \\
\hline TO-K & $5 Y 3 / 2$ & IOYR $4 / 2$ & $5 Y R 3 / 4$ & $5 Y R 3 / 4$ & 10YR 4/2 & IOYR 5/4 & $5 Y 2 / 1$ & $5 Y R 4 / 1$ & 10YR 4/2 & IOYR $4 / 2$ & $5 Y R 3 / 4$ & $5 Y R 4 / 4$ \\
\hline TN-VF & 5YR 5/6 & 1OYR $5 / 4$ & 5YR 5/2 & $10 R 7 / 4$ & 10YR $4 / 2$ & IOYR 5/4 & $5 Y 2 / 1$ & $5 Y 4 / 1$ & 5YR 5/2 & $5 Y R 5 / 2$ & $5 Y R 5 / 2$ & $10 R 6 / 2$ \\
\hline Boca 2 & $5 Y 2 / 1$ & $5 G 2 / 1$ & 10YR 2/2 & 1OYR $2 / 2$ & $5 Y R \quad 4 / 1$ & $5 Y R 4 / 1$ & N3 & $5 Y R 2 / 1$ & N3 & N3 & $5 R 6 / 2$ & $5 R 8 / 2$ \\
\hline NeroVite & N1 & N2 & N2 & N2 & $\mathrm{N} 2$ & N2 & $\mathrm{N} 2$ & N3 & N1 & N1 & N1 & N3 \\
\hline
\end{tabular}

Legend

Indoors (body type).

Outdoors for 3 months (italic). 


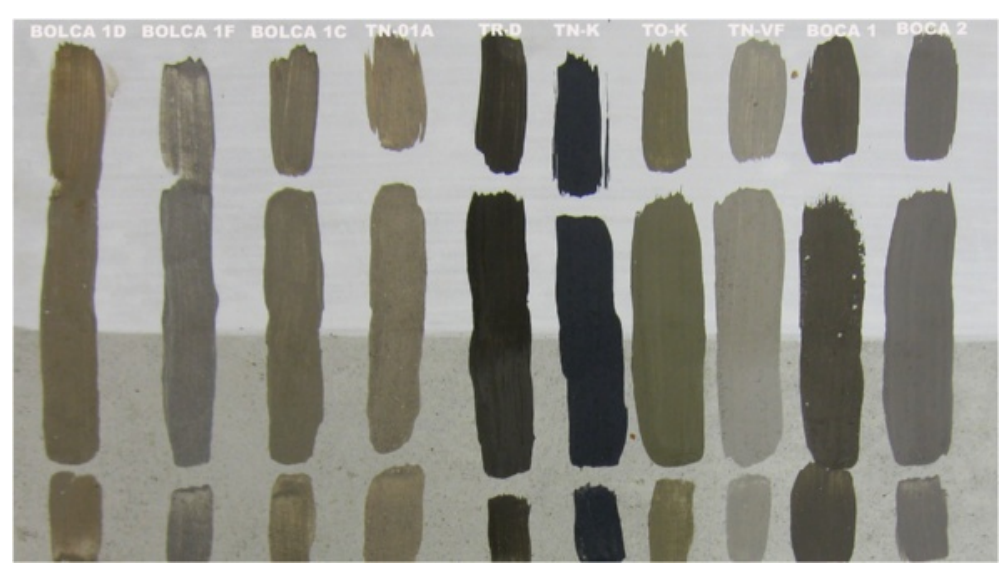

Figure 12 Replica of lime-based painting techniques using different black pigments: the picture shows the different colour of the black pigments both raw and manufactured after application with lime depending by the chemical composition and the particle size. The ground of the plaster (upper part) was smoothed with limewash whilst the surface of the lower part was left irregular. Pigments identification as follows, from left to right: Bol1d (5YR 5/6), Bolff (5YR 7/2), Bol1c (10R 7/4), TN01a (10R 7/4), TR-D (5YR 2/1), TN-K (5YR 2/1), TO-K (5YR 3/4), TN-VF (5YR 5/2), Boc1 (5YR 5/2), Boc2 (5YR 2/2).

comparing the relative intensities of the diffraction peaks. This is apparently due to the fact that the mechanical grinding - the action of the pestle in the mortar - produces agglomerations of clay particles which remain entrapped on the sieve while the microcrystalline calcite passed easily through. The finer material thus has a higher Cal/Mon ratio.

Furthermore, the material collected from the suspension is brownish while that from the bottom is black.

How do the compositions of these different particle size distributions and how organic and inorganic media influence the properties of the pigment when used in different painting techniques?

It seems that the final colour is strongly dependent on these parameters. Regarding grain size, the best results were obtained when the finest fraction extracted with dry and wet methods was used; in fact tinting strength of carbon-based pigments is dependent on particle size [1]. Naturally, the product available on the market gave very good results because its grain size and homogeneity have been carefully controlled industrially. Another important factor is the partial instability of the raw materials in air and sunlight as reported in Table 4. This behaviour was also noted in the case of charcoal black as carbon-based pigments produced by combustion may contain tarry material which can bleeds [2]. Finally, the collected black earths turned grey or faded when mixed with alkaline media such as lime and caseinates; this behaviour was not observed with commercially available black earths with similar mineralogical and chemical composition. On the other hand, good permanence was observed in the case of a fresco painting technique. An adequate discussion on this issue would require an indepth analysis of the composition of the C-based fraction and of possible impurities which seem to have an active role in the stability of some black pigments with alkaline media [1].

\section{Conclusions}

Analytical research carried out on black earths integrated with information collected from ancient written sources provides a better definition of these materials and sheds light on a more precise terminology for their variable compositions.

Black earth is a general term adopted to designate natural black earth pigments where both inorganic and organic compounds are present.

The presence of clay minerals, in association with iron oxides and carbonaceous matter, is a common feature of the studied raw materials. Optical microscopy observation distinguishes samples from black shale with laminar bedding (samples from Veneto) and samples from black chalk with non-laminated beds (samples from Piedmont) that would be otherwise impossible simply on the basis of XRD and XRF analysis.

Written sources report indications concerning the nature of black earths which find correspondences with analytical data. These include lignite and graphite from Piedmont; the term "ochre" which indicates the presence of clay minerals. In addition historical sources report that these materials can be potentially used in all painting techniques. The experimental application of the materials demonstrated that black earths have generally good properties as pigments. Depending on the nature of the analysed black earth, the grain size, the pictorial technique, the organic or the inorganic medium used, the final colour may sensibly change above all when exposed outdoors. 
Finally, it is noteworthy that no evidence on the use of black earths (black shale and black chalk) has been found to-date in murals and wall paintings. In our opinion, this is because they are very difficult to detect and can be easily confused with other carbon-based pigments.

We hope in the future to have the possibility to collect samples from wall paintings from monuments close to the studied geological sites and to investigate the composition of the black pigments.

\section{Competing interests}

The authors declare that they have no competing interests.

\section{Authors' contributions}

GC carried out all the issues concerning the scientific analysis, wrote and revised the manuscript. KGB developed the historic research and prepared the painting techniques replicas. Both authors read and approved the final manuscript.

\section{Acknowledgments}

We are grateful to Dr. R. Zorzin, senior conservator geologist and palaeontologist at the Civic Museum of Natural History in Verona (Italy), for his active collaboration in the research during the field work; to Prof. P. Scarzella and Dr. M. Zerbinatti of the Polytechnic of Turin (Italy) for their useful suggestions and for providing samples from Piedmont; to Mr. J. Gilardi, restorer and conservator, for his great support during the preparation of the replicas.

We are grateful to the two anonymous reviewers who contributed to improve the quality of the manuscript with their suggestions and comments.

\section{Author details}

'Dept. Earth and Environmental Sciences, University of Pavia, Via Ferrata 1 1-27010, Pavia, Italy. ${ }^{2}$ Institute of Materials and Constructions, DACD SUPSI CH-6952, Canobbio, Switzerland. ${ }^{3}$ Conservator of Architectural Surfaces, Canobbio, Switzerland.

Received: 24 July 2014 Accepted: 3 February 2015

Published online: 19 February 2015

\section{References}

1. Winter J, West FitzHugh E. Pigments based on carbon. In: Berrie B, editor. Artist's pigments, vol 4. Washington: National Gallery of Art; 2007. p. 1-37.

2. Winter J. The Characterization of pigment based on Carbon. Stud Conserv. 1983;28(2):49-66.

3. Spring M, Grout R, White R. 'Black Earths': a Study of Unusual Black and Dark Grey Pigments Used by Artists in the Sixteenth Century. In: National Gallery Technical Bulletin, 24, National Gallery Company Limited. 2003. p. 96-114.

4. Cavallo G, Zorzin R. Geology, Petrography, Mineralogy and Geochemistry of Natural Fe-based Pigments from Verona Province (Italy). In: Scott RB, Breakmans D, Carremans M, Degryse P, Leuven KU, editors. Proceedings of the 39th International Symposium on Archaeometry. 2014. p. 9-15.

5. Odin GS, Desprairies A, Fullagar PD, Bellon H, Decarreau A, Fröhlich F, et al Green Marine Clays. In: Odin GS, editor. Developments in sedimentology. Amsterdam: Elsevier; 1988. p. 337-98.

6. Odin GS, Fullagar PD. Green Marine Clays. In: Odin GS, editor. Developments in sedimentology. Amsterdam: Elsevier; 1988. p. 295-332.

7. Helwig K. Iron oxide pigments. In: Berrie B, editor. Artist's pigments, vol 4. Washington: National Gallery of Art; 2007. p. 39-109.

8. Cavallo G, Pandit M. Geology and petrography of ochres and white clay deposits in Rajasthan State (India). In: Kostov Rl, Gaydarska B, Gurova M, Sofia, editors. Proceedings of the conference Geoarchaeology and Archaeomineralogy. 2008. p. 147-52.

9. Federici F. Materiali utili del suolo e del sottosuolo della provincia di Verona. Verona: La Tipografica Veronese; 1948.

10. Scarzella GP, Natale P. Le terre coloranti e tinte naturali a base di terre, Stamperia artistica nazionale, Torino. 1989.

11. Color M. Geological Rock-Color Chart. USA: Geological Society of America; 2009.
12. Luzzato L, Pompas R. II significato dei colori nelle civiltà antiche. Milano: Bompiani; 1988.

13. Plinio Secondo Caio. Naturalis Historia, XXXIII-XXXVII, Ed. Giardini, Pisa. 1984

14. Cennini C. Trattato della pittura messo in luce la prima volta con annotazioni dal Cavaliere Giuseppe Tambroni, Ed. Co' Torchj, Roma, 1821

15. Vasari G. Le opere di Giorgio Vasari pittore e architetto aretino, Ed. David Passigli e Socj, Firenze, 1832

16. De la Hire M. Memoire de l'Academie Royale des sciences depouis 1666 jusqu'à 1699, IX, Ed. Par la Compagnie des Libraires, Paris 1730

17. Araus D P. Seminario economico compuesto de noticias practicas, curiosas y eruditas de todas Ciencias, Artes, Oficios, Ed. Imprenta de Andrés Ramirz, Madrid, 1766

18. Lewis W. Historie der farben. Ertse Abtheilung, von den Schwarzen Farben, Ed. Ben Heidegger und Companie, Zürich, 1766

19. Wallerio J G. Systema mineralogicum, quo corporamineralia in classes, ordines, genera et species, I, Ed. Officina Krawsiana, Vindobonae 1778

20. Mouchon P. Encyclopedie ou Dictionaire raisonné des sciences, des art set de metiers, Ed. Pellet L, Geneve, 1779

21. De Castro Palomino. El museo pictorico y escala optica. Teorica de la pintura, en que describe su origen, esencia, especies y qualidades, con todos los demas accidentes que la enriquecen è ilustran, l, Ed. Imprenta de Sancha, Madrid 1795

22. Tilloch A. The Philosophical magazine: comprehending the various branches of science, the liberal and fine arts, agriculture, manifactures and commerce, XV, Ed. Tilloch A, London, 1803

23. Bosellini A, Caffaro F, Corsi M, De Vecchi GP, Gatto GO, Malaroda R, et al. Descriptive comments to the Italian Geological Map, Scale 1:100.000 Sheet 49, Verona, Nuova Tecnica Grafica, Rome. 1967.

24. Siilvola J, Schmid R (2007): Lists of mineral abbreviations. Recommendations by the IUGS Subcommission on the Systematic of Metamorphic Rocks https://www.bgs.ac.uk/scmr/products/html.

25. Fellowes D, Hagan P. Pyrite oxidation: the conservation of historic shipwrecks and geological and paleontological specimens. In: Streeton N, editor. Reviews in Conservation. London: IC; 2003. p. 26-38.

\section{Publish with ChemistryCentral and every scientist can read your work free of charge \\ "Open access provides opportunities to our colleagues in other parts of the globe, by allowing anyone to view the content free of charge." W. Jeffery Hurst, The Hershey Company.}

- available free of charge to the entire scientific community

- peer reviewed and published immediately upon acceptance

- cited in PubMed and archived on PubMed Central

- yours - you keep the copyright

Submit your manuscript here:

http://www.chemistrycentral.com/manuscript/<smiles>c1ccccc1</smiles>

ChemistryCentral 